\title{
Preparing for and Recovering from Hurricane and Tropical Storm Damage to Tropical Fruit Groves in Florida 1
}

Jonathan H. Crane and Carlos F. Balerdi ${ }^{2}$

\section{Background}

Southern Florida has experienced numerous hurricanes and tropical storms. The most recent, hurricane Katrina (25-26 August 2005), made landfall in south Florida and was rated as a category 1 hurricane by the National Weather Service. Other recent hurricanes in 2004 (Charley, Frances, Jeanne, and Ivan) also affected commercial tropical fruit operations along the southeast and southwestern areas of Florida. In 1992, southeast Florida was devastated by Hurricane Andrew, a category 5 hurricane.

The Saffir-Simpson Hurricane Scale is a 1 to 5 rating based on the wind intensity of the hurricane and is useful in estimating the potential damage expected from a hurricane landfall. The scale is as follows: Category 1 hurricane, winds 74-95 $\mathrm{mph}$ (119-153 km/hr); Category 2 hurricane, winds 96-110 mph (154-177 km/hr); Category 3 hurricane, winds 111-130 mph (178-209 km/hr); Category 4 hurricane, winds 131-155 mph (210-249 km/hr) and; Category 5 hurricane, winds greater than $155 \mathrm{mph}(249 \mathrm{~km} / \mathrm{hr})$.
The estimated destruction to tropical fruit crops caused by recent hurricanes and tropical storms $(1992,1994,2004,2005)$ was in the hundreds of millions of dollars. As with the aftermath of previous hurricanes, growers are currently assessing their options, such as replanting, rehabilitating damaged trees, and repairing equipment and irrigation systems. They are also assessing their economic situation.

Winds from hurricanes may cause almost complete defoliation of all fruit crops, moderate to severe limb damage, severe trunk twisting and breakage, tree toppling, uprooting of entire trees, and the loss of almost all fruit (Campbell et al., 1993; Crane et al., 1993). Flooding during and after hurricanes may lead to root rot caused by low soil oxygen conditions and/or fungal diseases, and increased insect infestations (especially stem and trunk boring beetles). In addition to the direct effects of strong winds, wind-blown debris, such as loose sand and rock from adjacent open fields, may strip bark off of trees (sandblasting).

1. This document is HS1022, one of a series of the Horticultural Sciences Department, Florida Cooperative Extension Service, Institute of Food and Agricultural Sciences, University of Florida. First published as HS1022: September 2005. Please visit the EDIS Web site at http://edis.ifas.ufl.edu or http://fruitscapes.ifas.ufl.edu.

2. J. H. Crane, Professor and Tropical Fruit Crops Extension Specialist, Tropical Research and Education Center, Homestead, FL; C.F. Balerdi, Professor and Multi-County Fruit Crops Extension Agent III, Miami-Dade County, Homestead, FL; Cooperative Extension Service, Institute of Food and Agricultural Sciences, University of Florida, Gainesville, 32611.

The Institute of Food and Agricultural Sciences (IFAS) is an Equal Opportunity Institution authorized to provide research, educational information and other services only to individuals and institutions that function with non-discrimination with respect to race, creed, color, religion, age, disability, sex, sexual orientation, marital status, national origin, political opinions or affiliations. U.S. Department of Agriculture, Cooperative Extension Service, University of Florida, IFAS, Florida A. \& M. University Cooperative Extension Program, and Boards of County Commissioners Cooperating. Larry Arrington, Dean 
Grove infrastructure such as irrigation systems, tractors, roads, and farm buildings that house equipment and supplies, may also be heavily damaged by hurricanes and tropical storms.

\section{Pre-Hurricane Practices}

There are a number of planning practices that will help to minimize damage and speed recovery after a tropical storm or hurricane. These include planning for post-storm equipment needs; ranking groves as to their importance and repair potential; assessing the grove site and adjacent areas; and taking into account the previous preplant soil preparation practices and plant propagation methods used, the presence of windbreaks, and the current or needed tree size control practices.

\section{Planning}

Proper planning prior to a hurricane enables growers to make sound decisions before and after a storm and increases the chances of rapid recovery after the storm. Florida's hurricane season is from June to November each year. However, preparations for a hurricane should be made well before a tropical storm or hurricane watch or warning is announced. This is because cultural practices, such as pruning, topping, and hedging prior to a hurricane take time, labor, and equipment - all in short supply just before a hurricane.

Components of a hurricane plan should include insurance coverage for equipment, buildings, and orchards (including crop and tree loss); accumulation and safe storage of equipment needed for the recovery, such as saws, slings, shovels, fuel, paint, and equipment parts; and the knowledge of the location and cost of backhoes, front-end loaders, and wood chippers. Prioritizing which groves will be worth resetting, clearing, and replanting with the same or a different crop, or top-working is equally important.

\section{Site Selection}

Choice of a planting site is an important consideration that can affect the amount of hurricane damage. Natural woodlands can significantly reduce the velocity of winds during storms. They also reduce bark damage to fruit trees caused by wind-blown sand and gravel from open fields. Sites with planted windbreaks also afford some wind protection as long as the windbreak trees are well-rooted and have been topped, thus reducing the chances of their toppling into the adjacent fruit trees.

\section{Preplant Soil Preparation}

In Miami-Dade County, most tropical fruit crops are grown on a hard, but porous, oolitic limestone solid, commonly called Rockland or Krome soil (Calhoun et al., 1974; South Dade Soil and Water Conservation District, 1989; Noble et al., 1997). Typically heavy tractors with 42 -inch $(107 \mathrm{~cm})$ wide front-end plows ("rock plows") are used to scarify the limestone rock to a 4- to 8-inch (10- to 20-cm) depth. After rock-plowing, front-end trenching plows are used to make trenches [ 16 to 18 inches wide and 18 to 24 inches deep ( $41 \mathrm{~cm}$ to $46 \mathrm{~cm}$ wide and 46 to $61 \mathrm{~cm}$ deep)] in rows corresponding to tree rows and tree spacing distances (Colburn and Goldweber, 1961). Trees then are planted at the intersections of the crossed trenches, which greatly increases the depth and volume of soil available for rooting and anchoring trees.

Past hurricanes in southern Florida showed that preplant practices that increased the soil depth available for rooting increased tree stability during high winds. "Flat-planted" trees in rockland soil generally toppled during tropical storms and hurricanes, revealing a shallow, but extensive, lateral root system (Colburn and Goldweber, 1961). Observations after Hurricane Andrew suggested that some trees grown in cross-trenched groves broke off along the trunk, leaving only a jagged stump. Thus, while the tree was well anchored, the trunk could not withstand the wind stress. Hence there may be some argument for flat-planted trees that can be reset after toppling. However, in many cases, flat-planted trees were uprooted completely or blown away.

Tropical fruit trees planted in the shallow sands along the southeast and southwest coasts of Florida also have a restricted root zone due to high water tables (ground water levels). This also limits root anchoring and increases the likelihood of tree toppling. Construction of large, high beds may 
increase the extensiveness of the root system and improve tree anchorage during high winds.

\section{Grafted vs. Air-Layered Trees}

A number of fruit crops, such as lychee, longan, guava, and 'Tahiti' lime (no longer commercially produced in Florida to any extent) are commonly propagated by air layering (marcottage) for commercial planting in southern Florida. However, hurricanes during the 1940s and 1960s and Hurricane Andrew in 1992 revealed the grafted lime trees withstood the high winds, while air-layered trees were toppled or blown out of the ground. A survey of mature lime groves after Hurricane Andrew indicated that only $17 \%$ of the trees in groves established with air-layered trees survived while 93 to $96 \%$ of the trees survived in groves established with grafted trees (Crane et al., 1994). Guava groves established with air-layered trees and allowed to grow to approximately 12 to $15 \mathrm{ft}$ tall toppled whereas those pruned to 7 to $8 \mathrm{ft}$ remained in place. Thus, there is an effect of tree species, propagation method, and tree size on high wind tolerance.

\section{Tree Size Control Practices}

The canopies of trees, especially mature trees, resist wind movement, although there is much difference among species. If the wind is of sufficient speed and duration, trees may have leaves blown off, limbs broken, trunks snapped and/or twisted off (at or near the soil surface), or be toppled or blown out of the ground.

The most beneficial pre-hurricane cultural practice to reduce tree damage and toppling is a regular pruning program to control tree size. Tree size may be reduced by topping and hedging with heavy equipment (Newman, 1971; Phillips, 1972) and/or with hand-operated saws and pneumatic shears for selective limb removal. Other benefits of tree size control include ease of harvest, increased penetration and efficiency of foliar sprays, increased light and air penetration, retention of a lower bearing canopy, and improved equipment movement through the orchard.

A post-Hurricane-Andrew survey indicated that the percentage of trees toppling over and surviving varied with fruit species, the age of the trees, and the height prior to the storm. (Crane et al., 1994). In general, in groves where tree height was limited to 12 to $22 \mathrm{ft}$ ( 3.7 to $6.7 \mathrm{~m}$ ), more trees remained upright than in groves where no tree height control was practiced. In an avocado orchard rejuvenation study (Crane et al., 1992), the fewest toppled trees after Hurricane Andrew were in treatments where trees were topped to $12 \mathrm{ft}(3.7 \mathrm{~m})$. In contrast, more non-topped trees ( 30 to $60 \mathrm{ft}$; 9 to $18 \mathrm{~m}$ ) and trees topped to 16 to $22 \mathrm{ft}$ ( 4.9 to $6.7 \mathrm{~m}$ ), had fallen.

\section{Windbreaks}

The benefit of windbreaks depends on whether they withstand high winds, remain upright and mostly intact during a storm, or topple, uproot, and destroy the trees they were intended to protect.

In southern Florida, traditional flat-planted windbreaks of Australian pines resulted in heavy damage to fruit trees after a hurricane when they fell into the orchards (Brooks 1946; Loomis, 1946). In addition, they increased the grove restoration cost because windbreak trees had to be removed. Observations from previous hurricanes showed that no common windbreak species withstood hurricane winds in excess of $100 \mathrm{mph}(161 \mathrm{kph})$ without serious damage or uprooting (Ruehle, 1963). Similar problems with planted windbreaks were observed after Hurricane Andrew. However, an exception was mature, well established sapodilla trees, which appeared to be quite stable even against strong winds. It is recommended they be topped to $22 \mathrm{ft}(6.7 \mathrm{~m})$ or less to reduce their chances of toppling.

Human-constructed windbreaks have become common for carambola production in southern Florida. These windbreaks may be up to $22 \mathrm{ft}(6.7 \mathrm{~m})$ high and may surround an entire planting or just the portion of the grove perimeter not protected by natural windbreaks. Typically, they consist of aluminum or wooden poles with horizontal support cables from which shade cloth is attached vertically or on an incline to the cables. In most instances, groves are also sectioned-off inside the orchard with vertical shade cloth suspended 12 to $20 \mathrm{ft}$ (3.6 to 6.1 $\mathrm{m})$ above the orchard. These windbreaks work well to reduce wind speeds ( 5 to $36 \mathrm{mph}$; 2 to $16 \mathrm{~ms}-1$ or more) commonly experienced from November to 
March (Crane and Schaffer, 1992), thus allowing trees to grow vigorously and produce fruit (Crane, 1992). However, constructed artificial windbreaks were damaged during recent category 1 storms and did not survive the category 3 winds of Hurricane Wilma and the category 5 winds of Hurricane Andrew. On the other hand, groves adjacent to woodlands and planted windbreaks that had been topped had fewer toppled fruit trees and much less damage from windborne loose rock and sand than trees in unprotected groves.

\section{Irrigation Infrastructure}

Removing risers from the overhead and under-tree irrigation systems before a tropical storm or hurricane will dramatically reduce the amount of damage to risers and the underground piping of the system. During riser removal, plugging the riser bottom and open ground pipe with tape will greatly reduce debris entry and subsequent plugging of the irrigation system. Placing pumps and engines in an enclosed building also will reduce the chances of damaging them. However, moving such heavy equipment may not be practical.

\section{Post-Hurricane Practices}

The first step after a tropical storm or hurricane is to visually assess the damage and to estimated the cost and materials needed for resetting the grove. Once the equipment and labor have been assembled, debris removal, pruning of damaged trees, and resetting of toppled trees can begin.

Repairing or arranging for some type of functioning irrigation system should be one of the top priorities after the storm. This is because downed trees as well as trees uprighted after the storm will need access to water immediately to promote new root growth.

Trees should be reset as soon as possible after a hurricane. The timing, however, may depend on many factors, including the cost and availability of equipment and labor, and which groves or trees are deemed most valuable and/or saveable. The amount of root damage, the percentage of the root system remaining in the ground, and the amount of soil left around the exposed roots should be used to determine which trees to reset first. If possible, mounding soil on exposed roots or providing some type of shade will help keep the roots alive until resetting is possible.

\section{Equipment}

The equipment needed for resetting trees after a hurricane includes hand-pruning saws, chain saws, combination front-end loaders and backhoes, picks, shredders or chippers, shovels, hand hoes, loppers, and slings or large-diameter ropes for resetting fallen trees. Slings should not be made of cable or chain because they may damage the bark and cambial layer and may girdle already damaged and stressed trees. Cables also can be extremely dangerous to workers if they snap.

\section{Protecting Sun-Exposed Trunks and Limbs}

Cambial damage ("sunburn") may occur to defoliated and/or toppled trees exposed to direct sunlight for prolonged periods (Boyce, 1961; Levitt, 1980; Tattar, 1978). This injury is thought to be caused by overheating of the cambium layer, and symptoms include drying and peeling of the bark, defoliation, branch dieback, wood injury, and growth of saprophytic fungi on dead bark and wood.

Spraying or painting tree trunks and branches with white, water-based latex paint immediately after a hurricane will help prevent cambial overheating due to sun exposure. The latex can be diluted with water in a 1:1 ration (whitewash). If latex is not available, a whitewash can be made by mixing 1 part water, 1 part fine-grade hydrated lime, and 1/10 part zinc sulfate (1:1:01 ratio). For example, 1 gallon of water, $1 \mathrm{lb}$ of hydrated lime and 1/10 lb of zinc sulfate (3.785 liters of water, $454 \mathrm{~g}$ of hydrated lime and $45 \mathrm{~g}$ of zinc sulfate). The zinc sulfate should be dissolved in water first. For application purposes, the mixture can be diluted to the desired consistency with water. If the material is to be applied with a mechanical sprayer, it will have to be strained first and diluted further.

Piling brush on the exposed surfaces of major limbs and the trunk area will also aid in preventing sunburn damage. 


\section{Pruning}

Pruning may be a part of the debris removal and preparation for resetting toppled trees. Pruning cuts should be made back to sound wood, as in normal selective pruning practices. This includes pruning back to lateral buds, to the nearest crotch, or to the trunk. Additional pruning will be essential for proper tree management as new growth continues to develop and trees recover. In some cases, this may be a good time to cut trees back for topworking to more desirable cultivars.

Toppled trees also should be pruned back to sound wood. However, because of the extensive root damage of partially uprooted trees, a moderate to large amount of the tree canopy may have to be removed. Removing part or most of the canopy reduces the weight of the tree, making resetting and stabilizing the tree easier. It will also reduce the transpirational surface area. Depending on the size of the tree and the amount of damage, it may have to be cut back to main scaffold limbs or to the trunk (stump). Some trees may shift back to their original positions as the tops are removed. This can be dangerous for anyone pruning the tree or working near the root mass or trunk.

During the pruning process, braces for propping up trees may be made by cutting 4- to $10-\mathrm{ft}$ (1.2- to $3.1-\mathrm{m})$-long limbs of 4 to 6 inches $(10$ to $15 \mathrm{~cm}$ ) diameter with forked branches. These braces can be used to help stabilize trees after the resetting process.

Pruned-off branches can be stacked in the row for natural decomposition, removed from the orchard, chipped or shredded at the grove, or burned. Burning is not recommended because of air pollution, whereas chipped wood can be used immediately as mulch or composted for later use. Non-plant debris, such as metals, plastics, and rubber, should be removed and stacked outside the grove for later removal.

In some instances, when it is impossible to reset the trees immediately, pruning to remove most of the canopy of toppled trees will reduce transpiration and prevent desiccation. In addition, the pruned-off branches can be draped over the remaining trunk and scaffold branches for protection against sunburning.
However, keep in mind that this practice may provide protection for wood-boring insects from their natural enemies (S. Goldweber, personal communication) and the pruned branches may act as a bridge for weedy vines.

Once plant and non-plant debris have been removed and the orchard or some part of the orchard has been cleared, redigging planting holes and resetting fallen trees can begin.

\section{The Resetting Operation}

Before resetting a tree, lateral and vertical roots completely out of the ground and damaged roots should be removed with a lopper and/or a saw. This will enable the tree to stand level when reset. A backhoe or similar machine should be used to remove enough soil from the tree hole so that the tree will stand at or near the same level as before. Soil underneath the root mass of the fallen trees also may be removed by hoes and shovels.

Heavy-duty slings or ropes attached to tractors or backhoes can be used to assist in raising the trees to an upright position. Pre-cut braces can be used to stabilize or prop the trees after they are raised. The hole should be filled with excavated soil and the soil "flooded-in." The use of wood chips or other mulch on top of the soil is helpful in conserving moisture and controlling weeds.

\section{Irrigation Practices}

Invariably, irrigation systems are damaged to some extent during tropical storms or hurricanes. Irrigation systems should be repaired as soon as possible, because drought stress may cause dieback of new shoots and leaves, and may result in tree death. In addition, high-volume sprinkler irrigation systems need to be working for cold protection of cold-sensitive trees. We recommend irrigating at least twice per week at a 0.5 - to 1.0-inch (1.3- to $2.5-\mathrm{cm})$ rate per irrigation until trees become reestablished.

Salt damage to trees depends on plant tolerance, the salt concentration of the water and the duration of exposure in addition to whether the roots are immersed (salt water intrusion or tidal surge) and 
whether salt is deposited by wind (foliar). If irrigation is available after a storm, irrigation to wash salt off remaining foliage and to leach salts in the soil beyond the root zone will help reduce salt damage to sensitive trees.

\section{Fertilizer Practices}

Obtaining fertilizers and distributing them to reset or reconditioned trees may not be possible and/or may be of secondary importance immediately after a hurricane. However, major fertilizer elements should be applied when new growth begins to prevent nutrient deficiencies after stored reserves in the trees are depleted. Fertilizer rates for trees with limb loss should be reduced in proportion to the amount of tree damage, keeping in mind that previously fallen trees will have a damaged and much-reduced fibrous root system. More frequent light applications of low-analysis fertilizers may ensure a steady supply of nutrients and aid in a rapid recovery of canopy, limbs, and roots. In contrast, trees that lost mainly only leaves and remained upright should receive slightly higher-than-normal rates of fertilizer per tree as they reestablish their canopy. If possible, the fertilizer should be placed within a 3- to 6-foot (0.9to $1.8-\mathrm{m}$ ) area of the trunk. This is because the fibrous root systems of fallen trees probably have been reduced and damaged.

Micronutrients such as Mn and Zn commonly are applied to foliage in south Florida, especially in Miami-Dade County because the limestone-based soil has a $\mathrm{pH}$ of 7.5 to 8.5. As trees refoliate, micronutrients such as $\mathrm{Mn}$ and $\mathrm{Zn}$ should be applied to the leaves. Chelated iron soil drenches should be applied as the trees begin to refoliate.

\section{Weed Control Practices}

Weed control may be difficult after a storm due to a lack of equipment, materials, or labor. However, because more of the land surface area is exposed to direct sunlight, weeds and weed vines will proliferate. Weeds and vines will compete with the trees for sunlight, water, and nutrients and become more difficult to control as they mature. When row middles become accessible, mowing and herbicide applications should be resumed.

\section{Mulching Practices}

The use of mulch (wood chips) around the trees will be helpful in conserving soil moisture and reducing weed growth. Mulch should not be mounded against the trunks because continuous moisture along the trunk may facilitate attack by fungi and borers. The mulch should be kept at least 8 to 12 inches $(20$ to $30 \mathrm{~cm})$ from the trunk.

Some fruit tree species (e.g., lychee, mango, avocado) may be injured by thick layers of mulch and/or certain mulch materials. If in doubt, only weathered materials that are coarsely textured should be used and applied in thin layers of no more than 2 to 4 inches $(5$ to $10 \mathrm{~cm})$. Slightly increased fertilizer rates, especially of $\mathrm{N}$, may be necessary because some of the fertilizer will be used by micro-organisms decomposing the mulch into compost (Brady, 1974).

\section{Insect and Disease Control Practices}

Depending on location, various primary and secondary pathogens may attack defoliated and weakened trees. In addition, insect pests may attack what are usually considered non-host species. This may be due to a lack of normal host plant material or to decreased resistance of stressed plants. Local extension personnel should be contacted for identification and control recommendations.

\section{Post-Hurricane Andrew Observations}

The following observations on tree recovery after Hurricane Andrew (1992) may be useful examples of post hurricane care for specific species.

Atemoya and sugar apple. Most atemoya and sugar apple trees began to grow vigorously post storm, however, subsequently regrowth had chlorotic leaves and trees began to decline (Crane et al., 2001). Over the next 18 to 24 months, one or more cycles of new flush and shoot growth occurred followed by dieback. This was especially common for trees that had toppled during the storm and had been reset. The root system of atemoya and sugar apple trees appeared to be damaged by the resetting process; however, even those left leaning (not reset) showed 
marked iron deficiency and declined slowly. Subsequently, most atemoya and sugar apple trees were removed within 2 years of the storm.

Avocado. Trees reset or left standing after Hurricane Andrew recovered canopy and production rapidly during the next 7 years (Crane et al., 2001). Furthermore, overall industry production was only $20 \%$ below that of the season preceding the storm when commercial acreage was $25 \%$ higher.

Carambola. The vast majority of mature carambola trees refoliated quickly after the storm and bloomed twice: first, three to four weeks post storm with little fruit set; and again three to four weeks after the first bloom, this time setting a good crop. Post hurricane observations 14 to 15 months later of 4-year-old (young) 'Arkin' carambola trees indicated those trees that were declining had detached bark and or major roots at or below the soil line (Crane et al., 1994). Trees that were not heavily damaged appeared to recover well from the storm and little evidence of damage was noted 7 years later (Crane et al., 2001).

Guava. Guava trees began regrowth immediately after the storm, flowered on the new growth, and set a crop within 2 months; fruit was harvested 6 to 7 months later (Crane et al., 2001). Root sprouting from damaged roots was common resulting in multi-trunked trees.

'Tahiti' lime. Six to 12 months after Hurricane Andrew, lime trees had refoliated and some production was re-established (Crane et al., 2001). Seven years after the storm an estimated $80 \%$ of the surviving lime trees had recovered well. Rootstock sprouting and sunburn damage was somewhat of a problem.

Lychee and longan. Lychee production was greatly reduced for 1 to 2 years after Hurricane Andrew but trees generally recovered well and re-established a normal growth cycle. Six months after the storm, longan trees made a slow to moderate recovery; 10 to $20 \%$ were dying back. As with lychee, yields were low for 1 to 2 years and then re-established a normal pattern.
Mamey sapote. Two months and six months after the storm many mamey sapote trees were vigorously flushing (Crane et al., 2001). Some trees grew vegetatively for the next 4 to 5 years before resuming fruit production. Many previously damaged branches and weak new limbs have been observed to break since the hurricane.

Mango. Recovery of many mango trees after Hurricane Andrew was poor. In a post-storm survey four years later, about $20 \%$ of the mango trees that had previously toppled and been reset remained stunted and continued to slowly decline (Crane and Balerdi, 1997). Seven years after the storm $25 \%$ of the remaining mango trees were still declining (Crane et al., 2001).

\section{Conclusions}

Planning for a hurricane will help reduce damage to fruit trees and enhance recovery of the farming operation. The three most important pre-hurricane practices are the use of grafted plant material (for those fruits where this is a viable option), preparation of planting sites to increase rooting depth available for anchoring trees in place, and maintenance of a regular pruning program to limit tree size. After a hurricane, being prepared for clearing debris, repairing the irrigation system, resetting toppled trees, protecting trees from sunburn, and irrigating and fertilizing trees frequently will increase chances that the trees will recover and the farming operation will survive.

\section{Literature Cited and Further Reading}

Boyce, J.S. 1961. Forest pathology. McGraw-Hill, New York. p.38-39.

Brady, N.C. 1974. The nature and properties of soils, 8th ed. Macmillan, New York. p.150-163.

Brooks, J.R. 1946. Hurricane damage to commercial fruit trees in Dade County. Proc. Fla. State Hort. Soc. 59:149-151.

Calhoun, F.G., V.W. Carlisle, R.E. Caldwell, L.W. Zelazny, L.C. Hammond, and H.L. Breland. 1974. Characterization data for selected Florida soils. 
Univ. of Fla., IFAS Soil Sci. Dept., Soil

Characterization lab. and USDA Soil Conservation

Serv. Jan. 1974.

Campbell, R.J., C.W. Campbell, J. Crane, C. Balerdi, and S. Goldweber. 1993. Hurricane Andrew damages tropical fruit crops in south Florida. Fruit Var. J. 47:218-225.

Colburn, B. and S. Goldweber. 1961. Preparation of oolitic limestone soil for agricultural use. Proc. Fla. State Hort. Soc. 74:343-344.

Crane, J.H. 1992. The carambola. Fla. Coop. Extn. Serv., IFAS, Univ. of Florida, Gainesville. Fact Sheet FC-12.

Crane, J.H. and C.F. Balerdi. 1997. Effect of Hurricane Andrew on mango trees in Florida and their recovery. Acta Horticulturae 455:323-330.

Crane, J., C. Balerdi, R. Campbell, C. Campbell, and S. Goldweber. 1994. Managing fruit orchards to minimize hurricane damage. HortTechnology 4:21-27.

Crane, J.H., R.J. Campbell, and C.F. Balerdi. 1993. Effect of hurricane Andrew on tropical fruit trees. Proc. Fla. State Hort. Soc. 106:

Crane, J.H., A.J. Dorey, R.C. Ploetz, and C.W. Weekley, Jr. 1994. Post-hurricane Andrew effects on young carambola trees. Proc. Fla. State Hort. Soc. 107:338-339.

Crane, J.H. and B. Schaffer. 1992. Effect of wind speed on carbon assimilation, water relations, and growth of young carambola and sugar apple trees. HortScience 27:579 (Abstr.).

Crane, J.H., B. Schaffer, and R.J. Campbell. 2001. Recovery from hurricanes and long-term impacts on perennial tropical fruit crops in south Florida. HortScience 36:1-6.

Crane, J.H., B. Schaffer, T.L. Davenport, and C. Balerdi. 1992. Rejuvenation of a mature, non-productive 'Lula' and 'Booth 8' avocado orchard by topping and tree removal. Proc. Fla. State Hort. Soc. 105:282-285.
Crane, H.H., C. Balerdi, R. Campbell, C. Campbell, and S. Goldweber. 1993. Hurricane Andrew and south Florida's tropical fruit crops industry. The Fla. Grower and Rancher 86:25-27.

Levitt, J. 1980. Responses of plants to environmental stresses: Vol. 1, chilling, freezing, and high temperature stresses. Academic Press, New York. p.347-391.

Loomis, H.F. 1946. Hurricane damage to tropical plants. Proc. Fla. State Hort. Soc. 59:146-149.

Mosely, A.E. 1990. Economic impact of agriculture and agribusiness in Dade County, Florida. Industry Rpt. 90-4. Food and Resource Economics Dept., Univ. of Florida, Gainesville.

Newman, P.W. 1971. Current hedging and topping practices for avocados and limes in Florida. Proc. Fla. State Hort. Soc. 84:281-282.

Noble, C.V., R.W. Drew, and J.D. Slabaugh. 1997. Soil survey of Dade County, Florida. USDA-NRCS, Washington, D.C. p.1-161.

Phillips, R.L. 1972. Hedging angles for 'Hamlin' oranges. Proc. Fla. State Hort. Soc. 88:445-448.

Ruehle, G.D. 1963. The Florida avocado industry. Univ. of Florida Cooperative Extn. Serv. bul. 602 .

Tattar, T.A. 1978. Disease of shade trees. Academic Press, New York., p.209-212.

South Dade County Water Conservation District. 1989. South Dade Soil and Water Conservation District Rpt. Tentative soil legend, Dade County, Fla., Homestead. 